\title{
Ganglion cells in circumscribed astrocytic tumors: possible implication in classification and prognosis
}

\author{
Implicação da presença de células ganglionares na classificação \\ e evolução de tumores astrocíticos circunscritos
}

Veronica Goulart Moreira'; Nathalie Henriques Silva Canedo²; Leila Maria Cardão Chimelli ${ }^{3}$

\begin{abstract}
Introduction: Glial and neuroglial cell neoplasms comprise pilocytic astrocytoma (PA), pleomorphic xanthoastrocytoma (PXA) and ganglioglioma $(\mathrm{GG})$, which share various similarities, though PA has better prognosis. As ganglion cells (GC) may be scarce in GG and these gangliogliomas may recur or progress to grade III, an accurate diagnosis is essential. Objectives: The aim was to identify GC and eosinophilic granular bodies (EGB) in PA and PXA, to evaluate its effect on patient's outcome and compare them with GG. Methods: A retrospective analysis of radiological, morphological and follow-up aspects (disease free-survival, recurrence and death) of 30 cases (14 $\mathrm{PA}, 8 \mathrm{PXA}, 8 \mathrm{GG}$ ). Hematoxylin and eosin (HE) stained sections were reviewed to identify the presence of neoplastic GC and EGB. They were immunostained for synaptophysin (SYN) and neurofilament (NF). Glial fibrillary acidic protein (GFAP) immunostaining was performed in selected cases. Results: Six PA were reclassified as GG due to the presence of GC by HE or immunohistochemistry. Some EGB resembling degenerate GC were also immunostained for SYN/NF and most of them were negative for GFAP. The mean disease-free survival was 62.16 months. Four tumors recurred and one patient died. All PXA had GC, suggesting that they were variants of GG, 4 of which recurred and one patient died. Mean disease-free survival was 69 months. The radiological aspect was predominantly cystic. Conclusion: We propose that PA and PXA with GC or with EGB immunopositive for neuronal markers could be variants of GG, and some EGB may represent degenerate GC. However, the presence of GC does not seem to modify the biological behavior of these neoplasms.
\end{abstract}

Key words: pilocytic astrocytoma; pleomorphic xanthoastrocytoma; ganglioglioma; ganglion cell; eosinophilic granular bodies; classification.

\section{INTRODUCTION}

Glial and circumscribed neuroglial cell neoplasms comprise pilocytic astrocytoma (PA), pleomorphic xanthoastrocytoma (PXA) and ganglioglioma (GG), which share various similarities among each other ${ }^{(10)}$. PXA with ganglion cells and the association between PXA and GG have been reported in the literature ${ }^{(4,6,11-1,22,24)}$. Furthermore, the classical glial component of $\mathrm{GG}$ is generally pilocytic and, in some cases, the ganglion cells (GC) are scarce and may only be identified in focal areas.

Diagnostic practice at Hospital Universitário Clementino Fraga Filho (HUCFF) and Instituto de Neurologia Deolindo Couto
(INDC) revealed that PA generally recurred as GG. Moreover, we found GC in PA and PXA and eosinophilic granular bodies (EGB) in PA, PXA and GG, both with immunopositivity for neuronal markers.

As PA, PXA and GG share considerable similarities in terms of topography, image, affected age group and histological aspects, though there are some prognostic differences among them, we aimed at investigating these aspects comparing them with results from $\mathrm{GG}$.

Table 1 shows the main morphological, topographic, age and radiological characteristics shared among PA, PXA and GG, which are commonly described in the literature.

First submission on 18/06/12; last submission on 20/03/13; accepted for publication on 20/03/13; published on 20/06/13

1. Master's in Pathological Anatomy by Universidade Federal do Rio de Janeiro (UFRJ); pathologist at Universidade do Estado do Rio de Janeiro (UERJ), National Institute of

Traumatology and Orthopedics (Instituto Nacional de Traumatologia e Ortopedia [INTO]) and School Hospital Álvaro Alvim (Hospital Escola Álvaro Alvim [HEAA]).

2. Doctor in Biological Sciences (Biophysics) by UFRJ; associate professor at UFRJ-Pathological Anatomy Department.

3. Doctor in Neuropathology by University of London; professor at UFRJ-Pathological Anatomy Department. 
TABLE 1 - Morphological and radiological characteristics as well as tumor progression analyzed in PAs with or without ganglion component, PXA and GG expressed in absolute numbers and percentages (in parenthesis) for each group

\begin{tabular}{ccccc}
\hline & PA without ganglion component & PA with ganglion component & PXA & GG \\
\hline Eosinophilic granular bodies & $5(62.5)$ & $4(66.7)$ & $4(50)$ & $7(87.5)$ \\
Ganglion cells & $0(0)$ & $6(100)$ & $8(100)$ & $8(100)$ \\
Synaptophysin + & $0(0)$ & $6(100)$ & $8(100)$ & $8(100)$ \\
Neurofilament + & $0(0)$ & $2(33.3)$ & $8(100)$ & $8(100)$ \\
Synaptophysin in GC & $0(0)$ & $6(100)$ & $8(100)$ & $8(100)$ \\
Neurofilament in GC & $0(0)$ & $2(33.3)$ & $8(100)$ & $8(100)$ \\
Synaptophysin in EGB & $0(0)$ & $3(50)$ & $4(50)$ & $7(87.5)$ \\
Neurofilament in EGB & $0(0)$ & $1(16.6)$ & $4(50)$ & $7(87.5)$ \\
Infratentorial & $8(100)$ & $5(83.3)$ & $0(0)$ & $0(0)$ \\
Cystic & $4(50)$ & $5(83.3)$ & $4(50)$ & $4(50)$ \\
Tumor progression & $0(0)$ & $0(0)$ & $0(0)$ & $0(0)$ \\
\hline
\end{tabular}

PA: pilocytic astrocytoma; PXA: pleomorphic xanthoastrocytoma; GG: ganglioglioma; GC: ganglion cells; EGB: eosinophilic granular bodies.

\section{OBJECTIVES}

\section{General objectives}

To investigate the presence of ganglion cells in PA and PXA, correlate aspects of progression (disease free survival, relapse, tumor progression and death) and make comparisons with data from $\mathrm{GG}$.

\section{Specific objectives}

- To investigate the presence of neoplastic ganglion cells in PA, PXA and GG through morphological methods and immunohistochemistry for SYN and NF.

- To analyze if the use of neuronal markers contributed to the identification of ganglion cells.

- To characterize EGB with glial and neuronal markers (glial fibrillary acidic protein [GFAP], synaptophysin [SIN] and neurofilament $[\mathrm{NF}])$.

- To evaluate the possibility of reclassifying PA and PXA with ganglion component as ganglioglioma.

- To correlate morphological and immunohistochemical data with age and progression and compare them among $\mathrm{PA}, \mathrm{PX}$ and $\mathrm{GG}$.

\section{METHODS}

\section{Sample and origin}

Retrospective analysis of PA, PXA and GG, according to the World Health Organization (WHO), filed at Universidade Federal do Rio de Janeiro (UFRJ)-Pathological Anatomy Services and INDC/UFRJ from 1997 to 2011. The study includes 30 cases: 14 PA, 8 PXA and 8 GG (1 anaplastic). We reviewed medical records in order to identify patients, neuroradiological aspects and postoperative progress.

\section{Morphological analysis}

A diagnostic review and $\mathrm{GC}$ and $\mathrm{EGB}$ screening were undertaken. Moreover, the cases were morphologically analyzed through hematoxylin and eosin (HE).

\section{Immunohistochemical study}

The samples were submitted to immunohistochemistry with SYN and NF with the aim to better characterize and identify the ganglion component and its expression in EGB. Immunostaining with GFAP was carried out in cases in which there were EGB (Table 2).

TABLE 2 - Applied primary antibodies

\begin{tabular}{ccccc}
\hline $\begin{array}{c}\text { Antigenic } \\
\text { antibody }\end{array}$ & Clone & Manufacturer & Dilution & Retrieval \\
\hline Anti-neurofilament & 2FII & DAK0 & $1: 1800$ & Citrate buffer \\
Anti-synaptophysin & 5 np88 & Biogenex & $1: 200$ & Citrate buffer \\
Anti-GFAP & 6F2 & DAK0 & $1: 150$ & Citrate buffer \\
\hline GFAP: glial fibrillary acidic protein. & & &
\end{tabular}

\section{Statistical analysis}

Data were stored in only one database and statiscally analyzed. The statistical software XLSTAT- PRO 2009 PLS was applied and 
the statistical study was conducted through descriptive frequency, proportion and mean analyses as well as statistical tests.

\section{RESULTS}

\section{PA}

Six out of 14 PA demonstrated ganglion component by HE and/or positivity for SYN and/or NF on GC. Eight out of 14 PA did not present it.

Five from the PA with ganglion component were cystic, five were infratentorial, 4 had EGB and 6 had GC by HE. Four of them recurred and one progressed to death due to the neoplasm. There was no tumor progression. The age at diagnosis varied from 4 to 17 years (mean age: 10.66 years). The mean disease-free survival was 62.16 months. As to SYN marker, three cases exhibited positivity for EGB and all six cases presented GC. NF was positive for EGB in one case and for GC in two cases.

Four out of eight $\mathrm{PA}$ without ganglion component were cystic, all of them infratentorial, five presented EGB and none revealed GC by HE. Five of them recurred and one progressed to death in result of the neoplasm. Neither was there tumor progression, nor there was immunoreactivity for SYN and NF. The age at diagnosis varied from 3 to 37 years (mean age: 11.57 years). The mean disease-free survival was 18 months.

\section{PXA}

Eight PXA had ganglion component, four were cystic and all of them supratentorial. Four had EGB and eight GC by HE. Four of them recurred and one progressed to death. The mean disease-free survival was 69 months. There was no tumor progression. The age at diagnosis varied from 6 to 53 years (mean age: 30.25 years). As to SYN, four cases exhibited positivity for EGB and eight cases had positivity for GC. Some EGB immunostained with SYN and NF seemed to have degenerate nuclei.

\section{GG}

In the group of cases originally described as $\mathrm{GG}$, there were four relapses and one death, with no association among them. There was no tumor progression. The disease-free survival varied from 0 (GG grade III) to 24 months (mean time: 17.14 months). The age at diagnosis varied from 9 to 58 years (mean age: 27.75 years). Four of them were cystic, all of them were supratentorial, seven presented EGB and eight had GC by HE. As far as SYN is concerned, seven exhibited positivity for $\mathrm{EGB}$ and eight for GC. NF was positive for $\mathrm{EGB}$ in seven cases and positive for $\mathrm{GC}$ in eight cases.

\section{Morphological aspects}

\section{Ganglion cells}

Ganglion cells were detected in all six PA with ganglion component, in all eight PXA and in eight GG (Figures 1 to 4). Some had vacuolated cytoplasm and/or pyknotic nucleus suggestive of degeneration (Figure 1).

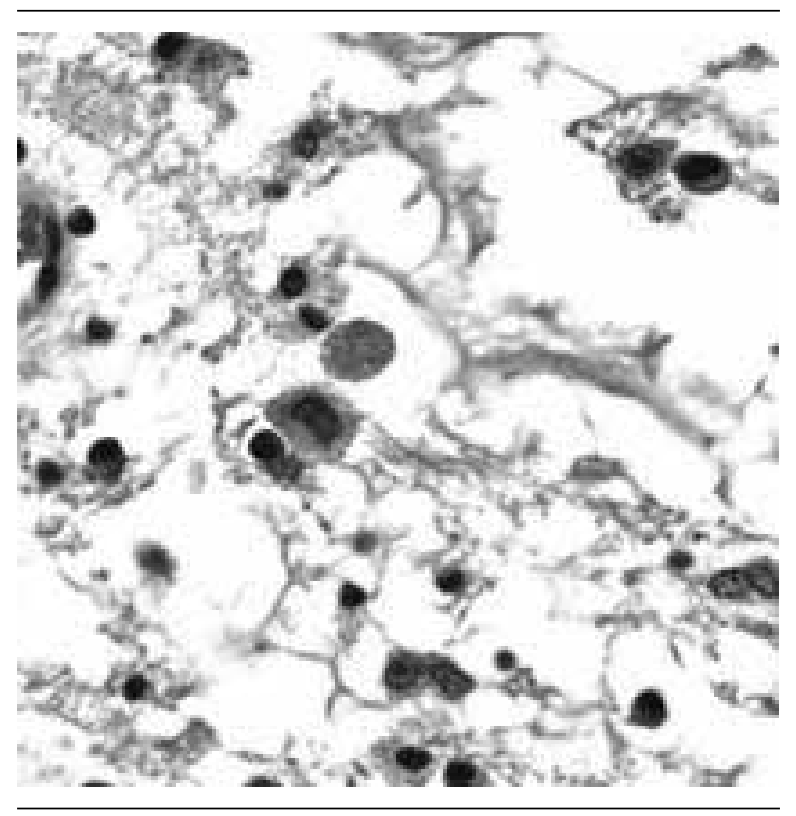

FIGURE 1 - Ganglion cell in pilocytic astrocytoma (HE, lens 40 $\times$ ) HE: hematoxylin and eosin.

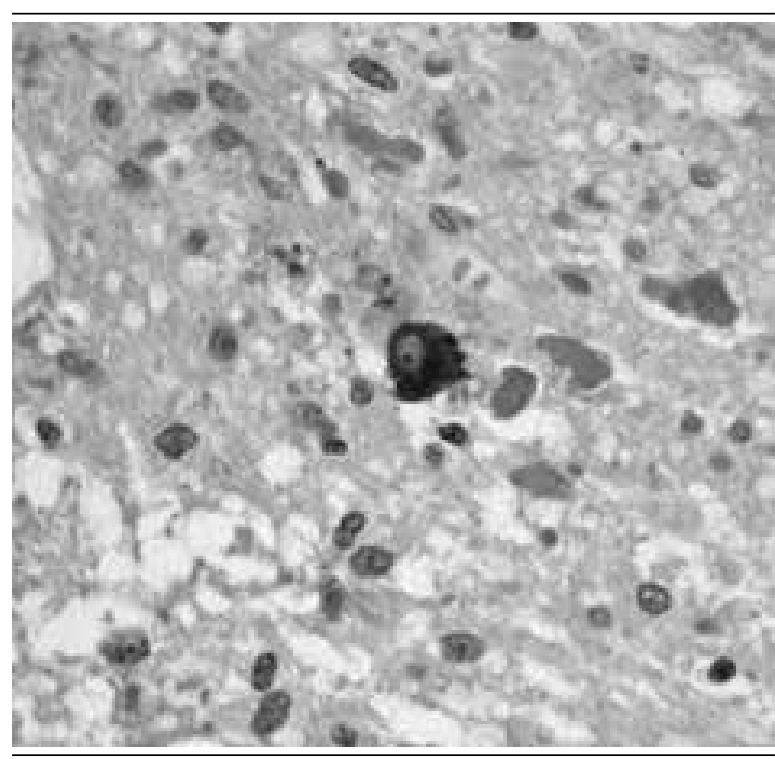

FIGURE 2 - Ganglion cell immunostained with SYN in pilocytic astrocytoma (lens 40 $\times$ )

SYN: synaptophysin. 


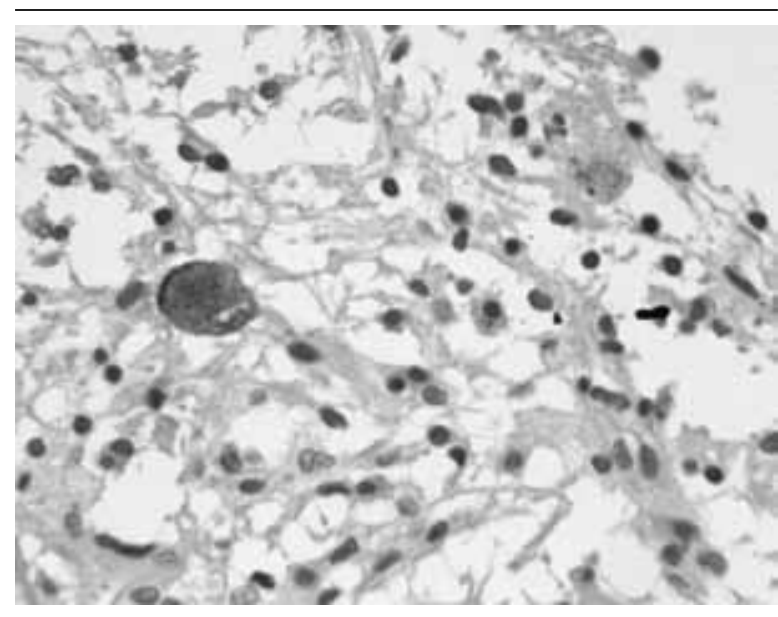

FIGURE 3 - Ganglion cell immunostained with NF with granular cytoplasm in pleomorphic xanthoastrocytoma (lens 40x)

NF: neurofilament.

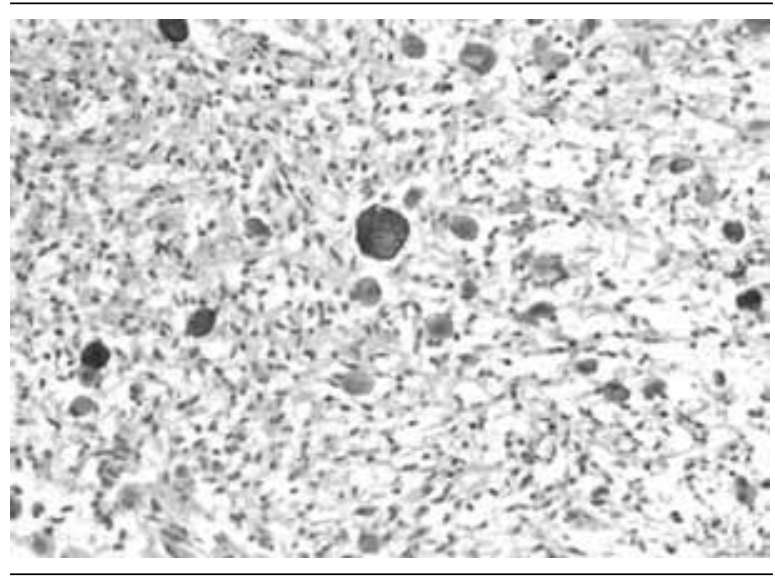

FIGURE 4 - Ganglion cell immunostained with NF in ganglioglioma. Note granular cytoplasm/microvacuolated (lens 10x)

NF: neurofilament.

\section{Eosinophilic granular bodies}

EGB were homogeneous, microvacuolar, eosinophilic and sometimes resembled hyaline droplets (Figure 5). In some of them, a possible negative image of the nucleus was observed. These structures were detected in five PA with ganglion component, four PXA and seven GG. As to SYN, 14 showed positivity. NF was positive for EGB in 12 cases and these were positive for both markers (Figures 6 and 7). GFAP was performed in five cases, from which four were immunonegative (Figure 8) and one was immunopositive.

Table 3 summarizes progression, radiological, histopathological and immunohistochemical findings.

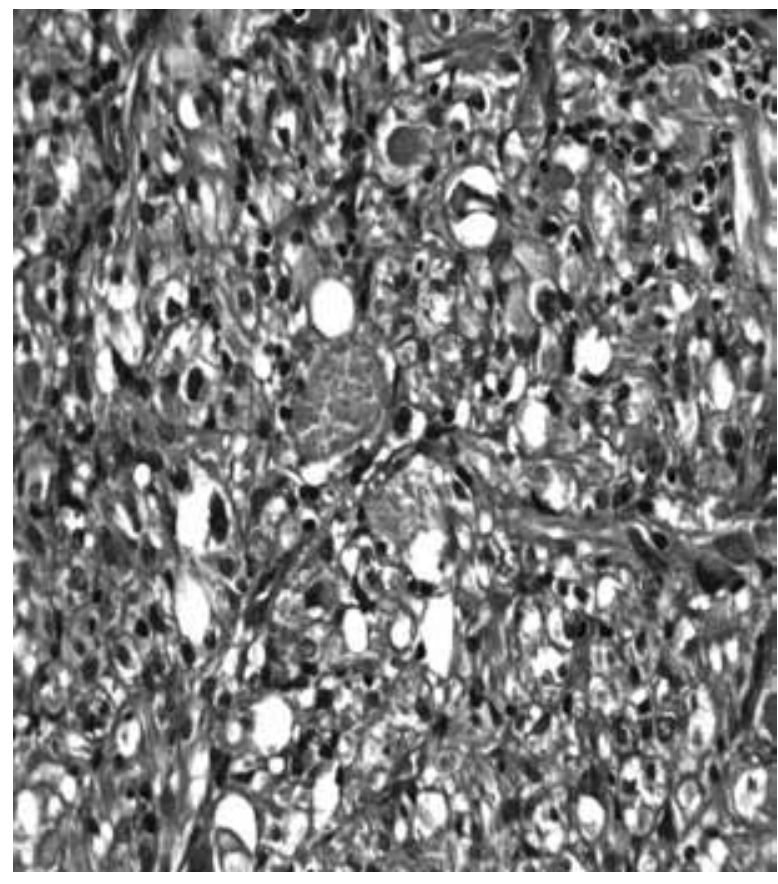

FIGURE 5 - Eosinophilic gramular body in pleomorphic xanthoastrocytoma in the center of the image (HE, lens 40x)

HE: hematoxylin and eosin.

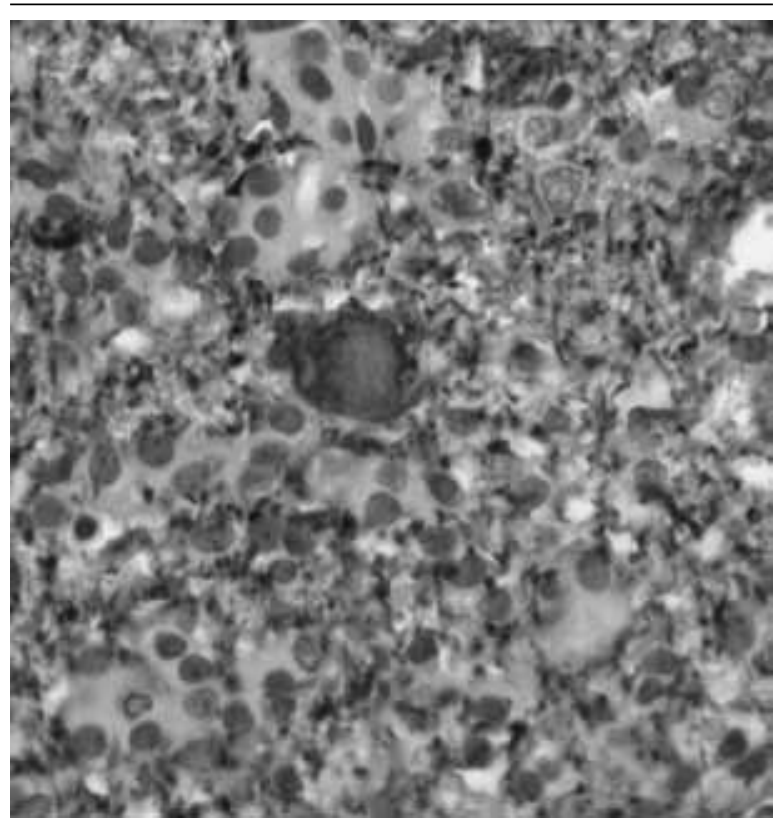

FIGURE 6 - Eosinophilic granular body immunostained with NF in ganglioglioma in the center of the image (lens $40 \times$ )

NF: neurofilament.

\section{Analysis of age, relapse and death}

The analysis revealed that the hypothesis of equality between age mean values should be rejected, inasmuch as there are significant differences between them $(\phi$ value $=0.010$ ). 


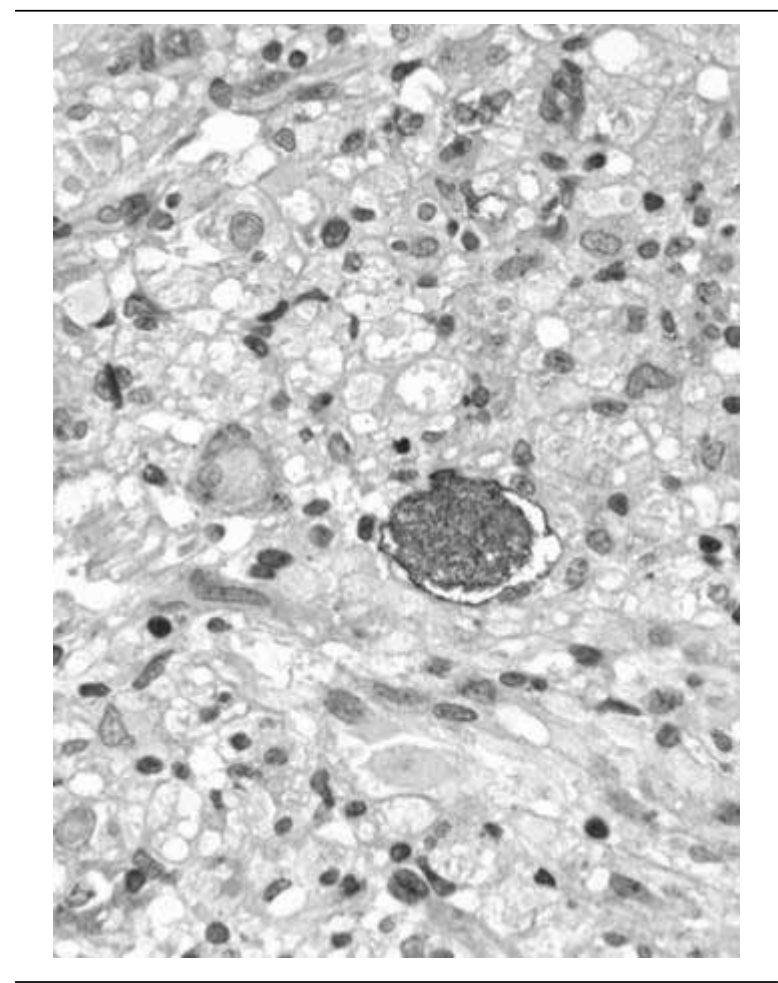

FIGURE 7 - Eosinophilic granular body immunostained with SYN in pleomorphic xanthoastrocytoma (lens 40x)

SYN: synaptophysin

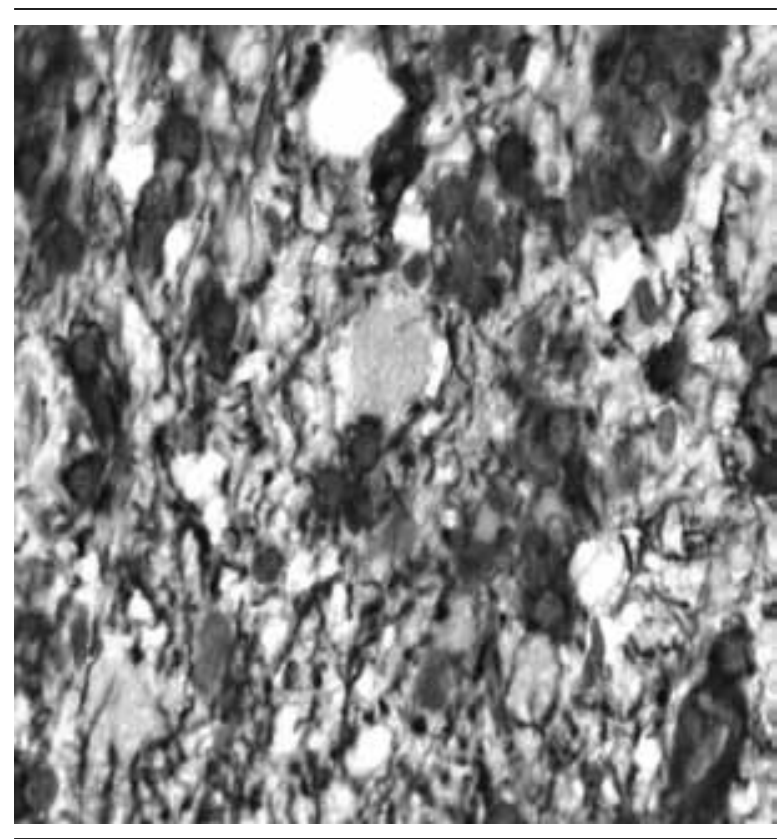

FIGURE 8 - Eosinophilic granular body negative for GFAP immunostaining in the center of the image (lens $40 \times$ )

GFAP: glial fibrillary acidic protein.

TABLE 3 - Morphological and radiological characteristics as well as tumor progression analyzed in PAs with or without ganglion component, PXA and GG expressed in absolute numbers and percentages (in parenthesis) for each group

\begin{tabular}{ccccc}
\hline & PA without ganglion component & PA with ganglion component & PXA & GG \\
\hline Eosinophilic granular bodies & $4(50)$ & $5(83.3)$ & $4(50)$ & $7(87.5)$ \\
Ganglion cells & $0(0)$ & $6(100)$ & $8(100)$ & $8(100)$ \\
SYN+ & $0(0)$ & $6(100)$ & $8(100)$ & $8(100)$ \\
NF+ & $0(0)$ & $2(33.3)$ & $8(100)$ & $8(100)$ \\
SYN in GC & $0(0)$ & $6(100)$ & $8(100)$ & $8(100)$ \\
NF in GC & $0(0)$ & $2(33.3)$ & $8(100)$ & $8(100)$ \\
NF in EGB & $0(0)$ & $1(16.6)$ & $4(50)$ & $7(87.5)$ \\
Infratentorial & $8(100)$ & $5(83.3)$ & $0(0)$ & $0(0)$ \\
Cystic & $4(50)$ & $5(83.3)$ & $4(50)$ & $4(50)$ \\
Tumor progression & $0(0)$ & $0(0)$ & $0(0)$ & $0(0)$ \\
\hline
\end{tabular}

PA: pilocytic astrocytoma; PXA: pleomorphic xanthoastrocytoma; GG: ganglioglioma; SYN: synaptophysin; NF: neurofilament; GC: ganglion cells; EGB: eosinophilic granular bodies.

The study on relapse and death was carried out in two phases and analyzing two groups. Firstly, the variables were compared among PA with ganglion component, PXA and GG. The second group comprised PA without ganglion component, PA with ganglion component and $\mathrm{GG}$. The analysis of the first group evinced a higher proportion of relapse and death among PA with ganglion component in comparison with PXA and GG (Table 4).
TABLE 4 - Absolute number and relapse and death proportion for $\mathrm{PA}$ with ganglion component and $\mathrm{GG}$

\begin{tabular}{cccc}
\hline & $n$ & Relapse & Death \\
\hline PA with ganglion component & 6 & $4(0.66)$ & $1(0.16)$ \\
PXA & 8 & $4(0.50)$ & $1(0.12)$ \\
GG & 8 & $4(0.50)$ & $1(0.12)$ \\
\hline
\end{tabular}

PA: pilocytic astrocytoma; PXA: pleomorphic xanthoastrocytoma; GG: ganglioglioma. 
The proportion of relapse and death between PXA and GG was the same.

Relapse: as calculated $p$ value $(0.2071)$ is higher than the significance level (alpha $=0.05)$, there is no significant difference in the relapse proportion between PA with ganglion component and GG. As to PXA and GG, based on sample results, the equality of proportions was concluded.

Death: as calculated $p$ value (0.3788) is higher than the significance level $(0.05)$, there is no significant difference in death proportions between PA with ganglion component and GG. AS to PXA and GG, based on the sample results, the equality of proportions was concluded.

According to Table 5, the second analyzed group showed relapse and death distribution.

TABLE 5 - Absolute number and relapse and death proportion for PA with and without ganglion component and GG

\begin{tabular}{cccc}
\hline & $n$ & Relapse & Death \\
\hline $\begin{array}{c}\text { PA with ganglion component } \\
\text { PA without ganglion } \\
\text { component }\end{array}$ & 6 & $4(0.66)$ & $1(0.16)$ \\
GG & 8 & $5(0.62)$ & $1(0.12)$ \\
& 8 & $4(0.50)$ & $1(0.12)$ \\
\hline
\end{tabular}

PA: pilocytic astrocytoma; GG: ganglioglioma.

Relapse: as $p$ value $(0.7971)$ is higher than the significance level $(0.05)$, there is no significant different within the three analyzed groups.

Death: as calculated $p$ value (0.9694) is higher than alpha significance level (0.05), it was concluded that deaths do not depend on diagnoses.

\section{Analysis of disease-free survival}

Variance analysis test (ANOVA) was performed and it was concluded that there was no significant difference among mean disease-free survival values $(\phi$ value $=0.210)$

\section{DISCUSSION}

In the neuropathology practice at UFRJ, PA have been reported in which, when conveniently investigated or in relapse, the ganglion component is present, which may imply a higher chance of relapse and malignant transformation when they are not resected.

In a more detailed investigation, as it was performed herein, we verified that six out of 14 exhibited ganglion cells expressed by HE, SYN and NF. All GCs were identified by HE, hence the immunohistochemistry was confirmatory. Therefore, we assume that the use of neuronal markers is not indispensable to the detection of GC in PA. It is essential to take into account that the diagnosis is not always simple, inasmuch as subjective interpretations may lead to diagnostic discrepancies or even the conclusion that $\mathrm{GC}$ are not present.

In 1994, Wasdahl et al. published a case of cerebellar PXA with pilocytic $\operatorname{areas}^{(21,23)}$, demonstrating similarities in the studied neoplasms. Among the common characteristics between PA and PXA, we highlight the radiological cystic aspect that was indentified in all PA, reclassified or not, in four out of eight PXA and in five out of eight $\mathrm{GG}$.

The ganglion component in PXA has been mentioned in other

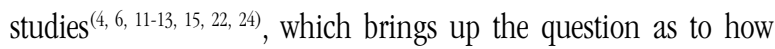
to denominate these tumors. Would they be PXA with ganglion component, true GG or collision tumors (association between PXA and $\mathrm{GG})$ ?

In our investigation, all eight PXA showed demonstrable ganglion component both by $\mathrm{HE}$ and immunohistochemistry. Accordingly, as it occurred with PA, the use of neuronal markers only confirmed the ganglion nature of the cells identified by HE. The positivity for these markers was verified in multinucleated and smaller atypical cells distributed in the tumors, which precludes the possibility of being a collision tumor or an infiltration of cortical neurons in the neoplasm peripheral area.

Immunopositivity for SYN had been described by Lindboe et al. in 1992 in an association of PXA and cerebellar GG. Nonetheless, these authors verified the positivity in only one region of the lesion (denominated $\mathrm{GG})^{(12)}$. This observation was made by Perry et al. in four cases of association between PXA and GG.

Anti-synaptophysin was positive in all cases and NF in three of them. Based on this observation, the authors questioned the possibility of being a GG with PXA as its glial component or PXA with neuronal component ${ }^{(9)}$. In 2008, Hirose et al. described 12 PXA, five with positivity for SYN, nine for NF and four for chromogranin $A^{(5)}$.

In 2003, Yeh et al. reported the association of PXA and suprasellar GG. In this case, there were ganglion cells indentified by HE and SYN was positive for these cells and giant ones ${ }^{(24)}$, which was also substantiated in our study.

Our results were closer to Powell et al. findings, who reported seven cases of PXA, all showing positivity for SYN and five of them for anti-NF${ }^{(15)}$. Herein, there was a higher proportion for $\mathrm{GC}$, which was detected in eight cases, both with the use of SYN 
and NF. Therefore, this suggests that PXA may be variants of $\mathrm{GG}$ whose neoplastic cells are lipidized or may constitute another glioneuronal tumor.

We did not find reports on $\mathrm{EGB}$ analysis and their identification through neuronal markers in none of the three tumors. In our investigation, EGB were observed by HE in four PXA, all confirmed by the positivity for anti-SYN and anti-NF; in seven GG, all confirmed by immunohistochemistry; in four out of six PA with ganglion component ; in five PA without ganglion component. Three of the PA with ganglion component showed positivity for SYN and one for NF

There was no positivity for EGB among PA without ganglion component. In the tumors with ganglion component that were positive for SYN and NF, it is possible that EGB may be degenerate $\mathrm{GC}$.

In 2002, Blümcke et al. described a series of $326 \mathrm{GG} .80 \%$ of the cases showed positivity for the following neuronal protein markers: microtubule - associated protein 2 (MAP-2), neuronal nuclei (NeuN) and $\mathrm{SYN}^{(2)}$. Despite the fact that our sample comprises less cases of GG (only eight), we verified positivity for SYN and NF in $100 \%$ of the cases, which corroborates the presence of ganglion component, indispensable to the diagnosis of these tumors.

In some cases, it was not possible to ascertain that the immunostained structures were ganglion cells in degeneration. In those cases in which the image suggested degenerate nucleus, immunostaining with NeuN (nuclear pattern) would be useful if this structure is negative for other neuronal markers.

GFAP was positive in only one case and negative in other four, all of them were GG and PXA that were immunopositive for neuronal markers, which denotes that EGB in these cases could represent degenerate ganglion cells and not astrocytic processes as it has been traditionally described.

In order to ascertain that the granular structures immunostained with SYN and NF antibodies were the same that were negative for GFAP, we may carry out a double immunostaining followed by examination on fluorescence microscope.

As to epidemiological aspects, we could observe that the mean age at diagnosis was 10,66 years for PA with ganglion component and 11.57 years for PA without ganglion component, which is corroborated by the literature. They are neoplasias that typically affect children and teenagers ${ }^{(3,17,20)}$. In PXA, the mean age at diagnosis was 30.25 years, varying from 6 to 53 , and five of them with less than 30 years. These results are similar to Hirose's findings (5) and higher than those reported by Kepes in the description of a series of 12 cases, whose mean age was lower $\left(12.75\right.$ years ${ }^{(9)}$. As to $\mathrm{GG}$, they occur predominantly among young patients, most of them younger than 30 years of age and with incidence peak between 10 to 20 years of age ${ }^{(2,7,16)}$, similarly to our sample results.

There was no tumoral progression (anaplastic or malignant transformation) in none of the 30 cases, despite the relapse and death due to the neoplasia, which corroborates the low grade of these lesions according to the classification proposed by the World Health Organization (WHO). These findings are also mentioned by Singhal et al., who claim that most PA tumors are relatively indolent ${ }^{(19)}$. Smith et al. also affirm that it is a neoplasia with rare malignant transformation, generally arising from radiotherapy ${ }^{(20)}$.

Anaplastic gangliogliomas have been described in the literature $^{(1,8,18)}$, but they are extremely rare. According to Blümcke et al., clinicopathological follow-ups identified a low risk of relapse and malignant transformation ${ }^{(2)}$. There was just one case of anaplastic GG in our study.

Our results contrast with those yielded by Hirose et al. in 2008, inasmuch as we did not observe any tumoral progression in PXA, which was reported by the authors in three cases that recurred ${ }^{(5)}$.

As to the identification of the ganglion component in $\mathrm{PA}$, PXA and GG and its relation with progression, we verified that the correlation of relapse, death and disease-free survival in PA with ganglion component, PXA and GG was not significantly different. These observations lead us to the conclusion that $\mathrm{PA}$ with ganglion component, PXA and GG have a similar behavior. PA without ganglion component also exhibited similar mean age, death and disease-free survival rates. However, we do not know whether these lesions were totally resected or not, since this piece of information was not available in the medical records. The incomplete resection may have contributed to a worse clinical progression.

\section{CONCLUSION}

PA and PXA may present ganglion component either by the presence of identifiable $\mathrm{GC}$ by $\mathrm{HE}$ or SYN and/or NF immunostaining, which are suitable antibodies for GC and EGB screening. However, they were not indispensable for the identification of GC in the present study.

The fact that all PXA presented GC conveys the possibility of being a glioneuronal tumor, perhaps a variant of GC. The presence of ganglion component in part of PA may imply that they may be GG whose ganglion component is not abundant or scattered throughout the neoplasm, that is to say concentrated on focal areas that may not have been sampled. EGB that display positivity for SYN and/or NF, associated with negativity for GFAP, may represent degenerate GC. 
The radiological cystic aspect was predominant, confirming that its presence may contribute to characterize circumscribed neoplasias.

The most affected age group, as it had been expected, comprised teenagers and young adults. The surveyed neoplasias present indolent biological behavior and most of them do not undergo anaplastic transformation, which is also corroborated by the literature.
There was relapse of neoplasias with ganglion component, but without significant difference in relation to those without it. As far as the lesion groups are concerned, there was no difference in terms of progression (relapse, death, disease-free survival and anaplastic transformation), which suggests that the presence of ganglion cells may modify the biological behavior of circumscribed astrocytic tumors.

\section{RESUMO}

Introdução: As neoplasias circunscritas incluem astrocitoma pilocítico (AP), xantoastrocitoma pleomórfico (XP) e ganglioglioma (GG), que compartilham diversas semelhanças, sendo o AP o de melhor prognóstico. Como as células ganglionares (CG) no GG podem ser escassas e os GGs podem recidivar ou evoluir (grau III), éfundamental o diagnóstico preciso. Objetivos: Identificar CG e corpos granulares eosinofilicos (CGE) em AP e XP, avaliar sua implicação na evolução e comparar com o GG. Métodos: Análise retrospectiva dos aspectos radiológicos, morfológicos e evolutivos (tempo livre de doença, recidiva e óbito) de 30 casos (14 AP, oito $X P$, oito GG). Cortes corados com hematoxilina e eosina (HE) foram revistos para a identificação da presença de CG neoplásicas e CGE. Estes foram imunomarcados para sinaptofisina (SIN) e neurofilamento (NF) e, em casos selecionados, para glial fibrillary acidic protein (GFAP). Resultados: Seis AP foram reclassificados para GG pela presença de CG (HE ou imunomarcação). Alguns CGE, semelhantes às CG degeneradas, também imunomarcaram para SIN/NF, a maioria sendo negativa para GFAP. O tempo médio livre de doença foi de 62,16 meses. Quatro tumores recidivaram; um deles evoluiu para óbito. Todos os XP possuíam CG, sugerindo que são variantes de GG, dos quais quatro recidivaram (um óbito). o tempo médio livre de doença foi de 69 meses. O aspecto radiológico foi predominantemente cístico. Conclusão: Sugerimos que AP e XP com CG ou CGE imunopositivos para marcadores neuronais possam ser variantes de GG e alguns CGE representem CG degeneradas; entretanto, a presença de CG ganglionares parece não modificar o comportamento biológico dessas neoplasias.

Unitermos: astrocitoma pilocítico; xantoastrocitoma pleomórfico; ganglioglioma; célula ganglionar; corpo granular eosinofílico; classificação.

\section{REFERENCES}

1. 1. BECKER, A. J. et al. Ganglioglioma and gangliocytoma. In: LOUIS, D. N.; OHGAKI, H.; WIESTLER, O. D.; CAVENEE, W. K. (Eds.). WHO classification of tumours of the central nervous system. 4. ed. Lyon: IARC, 2007. p. 103-5.

2. BLÜMCKE, I. et al. Gangliogliomas: an intriguing tumor entity associated with focal epilepsies. J Neuropathol Exp Neurol, v. 61, n. 7, p. 575-84, 2002.

3. BURKHARD, K. et al. Pilocytic astrocytoma of the elderly. Clin Neuropathol, v. 26, n. 6, p. 306-10, 2007.

4. FURUTA, A. et al. Temporal lobe tumor demonstrating ganglioglioma and pleomorphic xanthoastrocytoma components. Case report. JNeurosurg.v. 77, n. 1, p. 143-7, 1992.

5. HIROSE, T. et al. Pleomorphic xanthoastrocytoma: a comparative pathological study between conventional and anaplastic types. Histopathology, v. 52, p. 183-93, 2008.
6. IM, S. H. et al. Pleomorphic xanthoastrocytoma: a developmental glioneuronal tumor with prominent glioproliferative changes. JNeurooncol, v. 66, n. 1-2. P. 17-27, 2004.

7. JOHNSON, J. H. J. et al. Clinical outcome of pediatric gangliogliomas: ninety-nine cases over 20 years. Pediatr Neurosurg, v. 27, n. 4, p. 203-7, 1997.

8. KARREMAN, M. et al. Anaplastic ganglioglioma in children. J Neurooncol, v. 92, n. 2, p. 157-63, 2009.

9. KEPES, J. J. et al. Pleomorphic xanthoastrocytoma: a distinctive meningocerebral glioma of young subjects with relatively favorable prognosis. A study of 12 cases. Cancer, v. 44, n. 5, p. 1839-52, 1979.

10. KLEIHUES, P. et al. WHO grading of tumours of the central nervous system. In: LOUIS, D. N.; OHGAKI, H.; WIESTLER, O. D.; CAVENEE, W. K. (Eds.). WHO classification of tumours of the central nervous system. 4. ed. Lyon: IARC, 2007, p. 10-11.

11. KORDEK, R. et al. Pleomorphic xanthoastrocytoma with a gangliomatous component: an immunohistochemical and ultrastructural study. Acta Neuropathol, v. 89, n. 2, p. 194-7, 1995. 
12. LINDBOE, C. F. et al. Pleomorphic xanthoastrocytoma as a component of a cerebellar ganglioglioma: case report. Neurosurgery, v. 31, n. 2, p. 353-55, 1992.

13. PERRY, A. et al. Composite pleomorphic xanthoastrocytoma and ganglioglioma: report of four cases and review of the literature. $A m \mathrm{~J}$ Surg Pathol, v. 21, n.7, p.763-71, 1997.

14. PERRY, A. Glial and glioneuronal tumors. In: PRAYSON, R. A. (Ed.). Neuropathology. 1. ed. Philadelphia: Elsevier, 2005, p. 421-88.

15. POWELL, S. Z. et al. Divergent differentiation in pleomorphic xanthoastrocytoma: evidence for a neuronal element and possible relationship to ganglion cell tumors. Am J Surg Pathol, v. 20, n. 1, p. 80-5, 1996 .

16. PRAYSON, R. A. et al. Cortical architectural abnormalities and MIB1 immunoreactivity in gangliogliomas: a study of 60 patients with intracranial tumors.J Neuropathol Exp Neurol, v. 54, n. 4, p. 513-20, 1995.

17. SCHEITHAUER, B. W. et al. Pilocytic astrocytoma. In: LOUIS, D. N.; OHGAKI, H; WIESTLER, O. D.; CAVENEE, W. K. (Eds.). WHO classification of tumours of the central nervous system. 4. ed. Lyon: IARC, 2007, p. 14-21.
18. SCHNIEDERJAN, M. J. et al. Astrocytic neoplasms. In: Biopsy interpretation of the central nervous system. 1. ed. Philadelphia: Lippincott Williams \& Wilkins, 2011, p. 39-91.

19. SINGHAL, S. et al. Neurofibromatosis type 1 and sporadic optic gliomas. Arch Dis Child, v. 87, p. 1, p. 65-70, 2002.

20. SMITH, T. W. et al. Tumors of the nervous system. In: GRAY, G. U.; POIRIER, J. In: Basic neuropathology. 4. ed. Philadelphia: Butterworth Heinemann, 2004, p. 21-56.

21. SUGITA, Y. et al. Pleomorphic xanthoastrocytoma as a component of a temporal lobe cystic ganglioglioma: a case report. Brain Tumor Pathol, v. 26, n. 1, p. 31-6, 2009.

22. VAJTAI, I. et al. Pleomorphic xanthoastrocytoma with gangliomatous component. Orvosi Hetilap, v. 138, p. 16, p. 99-7, 1997.

23. WASDAHL, D. A. et al. Cerebellar pleomorphic xanthoastrocytoma: case report. Neurosurgery, v. 35, n. 5, p. 947-51, 1994.

24. YEH, D. J. et al. Composite pleomorphic xanthoastrocytomaganglioglioma presenting as a suprasellar mass: case report. Neurosurgery, v. 52, p. 6, p. 1465-9, 2003.

\section{MAILING ADDRESS}

Verônica Goulart Moreira

Rua Carvalho de Mendonça, 36, apto 202; Copacabana; CEP: 22020-050; Rio de Janeiro-RJ, Brazil; e-mail: veronicagmoreira@yahoo.com.br. 